INDEPENDENT JOURNAL OF MANAGEMENT \& PRODUCTION (IJM\&P)

http://www.ijmp.jor.br

v. 11, n. 4, July-August 2020

ISSN: 2236-269X

DOI: 10.14807/ijmp.v11i4.1031

\title{
INFLUENCE OF PRINCIPALS' SELF-MANAGEMENT ON THE ORGANISATIONAL COMMITMENT OF TEACHERS IN SECONDARY SCHOOL IN COUNTY GOVERNMENTS IN KENYA
}

\author{
Nancy Minjire Waweru \\ Jomo Kenyatta University of Agriculture and Technology, Kenya \\ E-mail:waweruwn@gmail.com
}

Hazel Gachunga

Jomo Kenyatta University of Agriculture and Technology, Kenya

E-mail:hazelgac@yahoo.com

John Mwaniki Kihoro

Co-operative University of Agriculture and Technology, Desconhecido

E-mail: kihoro.jm@gmail.com

Submission: 3/28/2019

Revision: 9/18/2019

Accept: 2/9/2020

\section{ABSTRACT}

Committed employees are likely to work harder and more efficiently, and stay in their jobs longer than less committed employees. Research indicate that the leader's self-management may influence the organizational commitment of employees as they feel good about working with such leaders since they are more likely to react to problems in a more controlled manner and may be more accommodative to different views of the subordinates. The purpose of this study was to investigate the influence of principals' (head of secondary schools) selfmanagement on the organizational commitment (OC) of teachers as moderated by teachers' self-efficacy. The dependent variable in this study is OC, while the independent variable is self-management (a dimension of emotional intelligence) and the moderating variable is teachers' self-efficacy. This study hypothesized that principal's self-management has no significant relationship on teachers' OC. Simple random sampling was used to draw a sample of 120 principals and 480 teachers from secondary schools in Nairobi, Machakos, Kajiado, and Kiambu counties in Kenya. A survey questionnaire was used to collect data from the respondents. Collected data was analyzed through independent samples $t$-test, descriptive statistics, correlation analysis and multiple regression. The study established that principals' self-management had a significant correlation with teachers’ OC. 
DOI: 10.14807/ijmp.v11i4.1031

It also established that teachers' self-efficacy moderated the relationship between principals' self-management and teachers' OC and that self-efficacy had positive influence on teachers OC. This study makes useful contribution in the advancement of knowledge on the influence of principals’ self-management on teachers' OC in Kenya.

Keywords: Self-management, Organizational commitment, Self-efficacy

\section{INTRODUCTION}

There has been a surge in the interest and attention on organizational commitment literature (MEYER; HERSCOVITCH, 2001, COLQUITT; LEPINE; WESSON, 2009) because of its potential benefit to the organization and individual employee. Employees who experience high organizational commitment are theorized to display positive organizational behaviors, such as better job performance and organizational citizenship activities which will definitely benefit the organization (ALBDOUR; ALTARAWNEH, 2014).

Organizational commitment also helps to preserve well qualified and talented individuals which leads to the stability of an organization. Committed employees are also less often absent and are less likely to leave the organization voluntarily than the less committed employees.

According to Mowday (1998) committed employees are likely to work harder, more efficiently and stay in their jobs longer than less committed employees. Therefore, organizations such as schools aspire to have employees who are committed towards the achievement of the organization goals. Organizational commitment is defined as the degree to which an employee identifies with the organization and wants to continue active participation in it (NEWSTROM; DAVIS, 1997).

The 1990s saw a great deal of attention on emotional intelligence (EI) as researchers argued that certain abilities predicted success in life other than the academic success. Khosravi et al. (2011) suggests that emotional intelligence concept goes back to the era of intelligence testing movement, when Professor Thorndike expressed the theory of social intelligence. However, EI only gained popularity and academic attention as a result of the publication of Daniel Goleman‘s book entitled- Emotional Intelligence: Why It Can Matter More Than IQ. Goleman (1995) defined emotional intelligence as a capacity for recognizing our own and others' feeling, for motivating our self and for managing our emotions, both within ourselves 
INDEPENDENT JOURNAL OF MANAGEMENT \& PRODUCTION (IJM\&P)

http://www.ijmp.jor.br

v. 11, n. 4, July-August 2020

ISSN: 2236-269X

DOI: 10.14807/ijmp.v11i4.1031

and in our relationships. He claimed that EI is as powerful and at times more powerful than IQ in predicting success in life.

Self-efficacy was first introduced by Bandura who defined it as the beliefs in one's capacity to organize and execute the courses of action required to produce given attainments (BANDURA, 1997). Self-efficacy does not represent a generalized feeling of control, but rather individuals' comprehensive judgement of their capability to perform a particular job (GIST; MITCHELL, 1992). The introduction of this concept sparked many organizational researches in areas such as sport, politics, health, and academics. This is because self-efficacy beliefs influence the course of action that people pursue, and is an important construct for understanding human behavior in various contexts (BANDURA, 1986; BANDURA, 1997). It also strongly influences the choices people make, the effort they expend, and their perseverance in the face of challenge (BANDURA, 1986).

Recently, self-efficacy has become the focus of attention in the field of teaching since it has been found to be one of the important variables consistently related to positive teaching behavior such as commitment. This is because teachers with higher teaching efficacy find teaching meaningful and rewarding, expect students to be successful, assess themselves when students fail, set goals and establish strategies for achieving those goals, have positive attitude about themselves and their students, have a feeling of being in control, and share their goals with students (ASHTON, 1985).

According to Adedoyin (2010), efficacious teachers are more likely to stay in teaching, put more time in it and show greater effort in classroom planning and organization and greater enthusiasm for teaching. Similarly, a teacher with a high sense of efficacy portrays more enthusiasm for teaching, has greater commitment to teaching, and is more likely to stay as a teacher (TSCHANNEN-MORAN; HOY; HOY, 1998).

However some researchers found no correlation between efficacy in teachers and organization commitment. For instance, Murphy (2013) study on the relationship between teacher efficacy and organizational commitment showed that teachers' efficacy did not correlate with organizational commitment, and personal teaching efficacy did not correlate with affective commitment.

Heading a school is a complex responsibility and principals require more than just IQ and as Goleman (1998b) pointed out EI and its dimension such as self-management is the sine qua non of leadership and argues that without it one will not make a great leader. Principals 
INDEPENDENT JOURNAL OF MANAGEMENT \& PRODUCTION (IJM\&P)

http://www.ijmp.jor.br

v. 11, n. 4, July-August 2020

ISSN: 2236-269X

DOI: 10.14807/ijmp.v11i4.1031

are entrusted with the task of leading their school, making decisions, influencing and guiding the activities of their schools toward achieving their goals. They are responsible for administering all aspects of their school's operations as well as working and improving relationship with the entire school stakeholders. As they relate with these groups they not only have to learn how to manage their emotions but must also manage others emotions.

\subsection{Problem Statement}

Organizational commitment (OC) has been associated with positive organizational behavior such as decreased employee turnover rate and absenteeism (MEYER; HERSCOVITCH, 2001; SOLINGER; VANOLFFEN; ROE, 2008; TURUNEN, 2011). Over the years however concerns have been raised regarding the lack of commitment among teachers as evidenced by a great number of teachers leaving the profession, frequent industrial actions, a high number of teachers missing school, and others failing to attend class even if they are in school. A recent study by Kenya National Union of Teachers (2015) indicates that more than 200,000 (807 of them being secondary school teachers or 76 per cent) of teachers in public schools wish to leave teaching because of professional needs such as promotion and personal needs which include salaries and allowances.

A teacher who is less committed is likely to put less effort in their work compared to one with high level of commitment. Zeidner; Roberts; Matthews (2002) argues that EI (and its related dimension) provides the medium by which educational reforms can and finally will reach its full potential, across primary, secondary, and tertiary level of school. Salami (2008) argues that regulation of one's emotions as well as those of others are factors that affect interpersonal relations in the workplace which means leader's self-management may influence the OC of employees. Therefore this study sought to establish whether principals' selfmanagement had an influence on OC of secondary school teachers.

\subsection{Significance of the Study}

As school principals execute their roles and responsibilities they experience multiple challenges which require specific skills to overcome them. Schools also involve daily social interactions between the principal, students and other key stakeholders (e.g., parents, teachers, education officials etc.). This implies that a principal must not only take into consideration his or her own emotions but also those of others. Research has shown that EI (GOLEMAN, 1998b; GEORGE, 2000; WILLIAM, 2008) distinguish between outstanding leaders and typical performers. Regulation of one's emotions (self-management) as well as understanding other 
DOI: 10.14807/ijmp.v11i4.1031

people's emotions affects interpersonal relations in an organization hence influencing organizational commitment of employees (SALAMI, 2008).

Since this study has established that principals' self-management significantly influence teachers' OC it will go a long way in informing the TSC on the importance of selfmanagement to principals. The knowledge will inform the TSC on the need to implement training policies that will help improve self-management among secondary school principals. It will also be beneficial to the TSC since it will inform them on competencies to look for as they recruit new principals.

\subsection{Objective of the study}

The purpose of this study was to investigate the influence of principals' selfmanagement on organizational commitment of secondary school teachers as moderated by teachers' self-efficacy in county governments in Kenya.

\subsection{Study hypotheses}

1. There is no significant influence of principal's self-management on the organizational commitment of teachers.

2. There is no significant moderating influence of self-efficacy on the relationship between principal's self-management and organizational commitment of teachers.

\section{LITERATURE REVIEW}

\subsection{Self-Management}

Self-management is defined as the ability to control disruptive or harmful emotions (DAFT, 2008) or the ability to regulate distressing affects like anxiety and anger and to inhibit emotional impulsivity (GOLEMAN, 2001). It involves keeping disruptive impulses in check, displaying honesty and integrity, being flexible in times of change, maintaining the drive to perform well and seize opportunities, and remaining optimistic even after failure. People with this competence are able to keep in check their emotions and stay focused even under pressure.

George (2000) contends that self-management captures individual differences in the extent to which one is able to successfully manage moods and emotions. Self-management include six competencies; emotional self-control, transparency, adaptability, achievement orientation, initiative and optimism. Self-control involves managing disruptive emotions and impulses and channeling them in a useful way. 
DOI: 10.14807/ijmp.v11i4.1031

Transparency has to do with maintaining honesty and integrity, openness about one’s feeling, admitting one's mistakes, and taking responsibility of one's performance (GOLEMAN; BOYATZIS; MCKEE, 2002). Adaptability means flexibility in handling change which make people to smoothly handle multiple demands, shifting priorities, and rapid change (GOLEMAN, 2001).

Achievement orientation is a drive to improve or meet a standard of excellence. People with this competence are results-oriented, with a high drive to meet their objectives and standards, set challenging goals and take calculated risks, and learn how to improve their performance (GOLEMAN, 2001). Initiative is defined as readiness to act and seize opportunities or create them. Lastly, optimism involves seeing the positive side of an event and keeping on pursuing goals even when one is faced with setbacks. Optimistic people always see the positive side of a situation and even in challenges.

\subsection{Self-efficacy}

The concept of self-efficacy was introduced by Bandura (1986) in his social cognitive theory. Bandura, (1997) defined self-efficacy as the beliefs in one's capacity to organize and execute the courses of action required to produce given attainments. According to Bandura (1997), principal self-efficacy is the judgment of principal capabilities to structure a particular course of action in order to produce desired outcomes in the school he or she leads. These efficacious beliefs and judgments about personal capabilities and not their skills drive people to accomplishing their set goals.

What people believe is more powerful than the abilities for a particular task and affects how one behaves and his/her motivation. How a person feels (efficacy) about a circumstance will determine not only the behavior, but also the outcome, once a person evaluates what kind of outcome to expect (Murphy, 2013). This was in line with what Bandura (1997) proposed that one's behavior is determined by both outcome expectancy and efficacy expectations.

Research on teachers' self-efficacy has attracted great attention among researchers (GUSKEY; PASSARO, 1994; TSCHANNEN-MORAN, et al., 1998: CAPRARA et al., 2006). This is because teachers with a higher sense of efficacy exhibit greater enthusiasm for teaching (ALLINDER, 1994), are persistent when things do not go smoothly and are resilient in the face of setbacks (MILNER; HOY, 2003), and have greater commitment to teaching (COLADARCI, 1992). 
INDEPENDENT JOURNAL OF MANAGEMENT \& PRODUCTION (IJM\&P)

http://www.ijmp.jor.br

v. 11, n. 4, July-August 2020

ISSN: $2236-269 X$

DOI: 10.14807/ijmp.v11i4.1031

Tschannen-Moran, et al. (1998) found that teachers' efficacy affects their behaviors, effort, innovation and organization, persistence, willingness to work with difficult students and commitment to the job. It would also be expected that a teacher with a strong sense of efficacy will be more willing to assist students with learning difficulties, ready to listen to parents concern, and more willing to adopt new strategies that are of benefit to student learning. Teachers' sense of efficacy influences how much effort one invests in an endeavour.

Teacher self-efficacy was defined as teacher's belief in his/her capability to organize and execute the courses of action required to successfully accomplish a specific teaching task in a particular context (TSCHANNEN-MORAN et al., 1998). As much as believing that one has the capability to execute necessary changes to achieve the desired outcomes, one must also believe that he/she has the skills required to be successful. That is why Bandura (1997) asserted that these beliefs were more powerful than one's actual abilities for the task at hand in influencing people’s level of motivation, affective states, and actions.

The source of teachers' self-efficacy includes; mastery experiences, physiological and affective states, vicarious experiences, and social persuasion. Mastery experiences which are defined as individual past successful experiences are believed to be the most powerful source of efficacy (TSCHANNEN-MORAN et al., 1998). The reason for this is because people are most likely to believe they can be successful when they have been successful in the past (CHERNISS; GOLEMAN, 2001).

If a teacher's past performance was successful it raises the efficacy beliefs but failure lowers the beliefs. For instance, a teacher whose subject excelled in the national examination will have the expectations that future performance will be better. Gutskey; Passaro (1994) postulated two facets of teachers' self-efficacy; general efficacy and personal efficacy. They defined general efficacy as teachers' beliefs in the ability of teachers (in general) to influence student outcome while personal efficacy is teacher's belief that he/she personally has the skills necessary to affect positive student outcomes in the face of adversity or difficulty. This study will deal with personal efficacy as it will only consider individual principals and their teachers' belief. As Tschannen-Moran; Woolfolk, Hoy (2001) found out general efficacy scale is least successful in capturing the essence of efficacy.

\subsection{Organizational commitment}

Organizational commitment (OC) has been the focus of numerous studies. This may be due to the fact that OC has been associated with positive organizational behavior such as extra- 
DOI: 10.14807/ijmp.v11i4.1031

role behavior, decreased employee turnover rate and absenteeism (MEYER; HERSCOVITCH, 2001, SOLINGER; VANOLFFEN; ROE, 2008, TURUNEN, 2011). Newstrom \& Davis (1997) defines OC as the degree in which an employee identifies with the organization and wants to continue active participation in it. According to Colquitt, et al. (2009) OC is the desire on the part of an employee to remain a member of the organization. Mowday (1998) posits that OC has three related factors: a strong belief in and acceptance of the organization's goals and values; a willingness to exert considerable effort on behalf of the organization; and a strong desire to maintain membership in the organization.

Despite these many definitions, there is no agreement on the definition of OC. Hence Meyer; Allen (1991) suggested that one must specify the definition he/she uses to avoid confusion. The duo developed the most widely accepted and most dominant multidimensional commitment framework referred to as the three-component model (TCM). This model consists of three dimensions namely; affective commitment, continuance commitment and normative commitment. Affective commitment (AC) is defined as employees' emotional attachment to, identification with, and involvement in the organization (SOLINGER, et al., 2008). Continuance commitment (CC) refers to an awareness of the costs associated with leaving the organization (MEYER; ALLEN, 1997) whereas normative commitment (NC) refers to employees' feelings of obligation to the organization

Many other forms of OC have been examined (COHEN, 2006; MATHIEU; ZAJAC, 1990; COHEN, 1999). For example, Cohen (2006) studied organizational and occupational commitment whereas Mathieu; Zajac (1990) referred to attitudinal and calculative commitment. Allen; Meyer (1990) and Meyer; Allen (1997) studies found that OC is a multidimensional construct. Cohen (1999) studied affective organizational commitment, continuance organizational commitment, career commitment, job involvement and work ethic endorsement. Since an employee relates with the organization, one can express different degrees of each of the constructs. This study adopted Meyer; Allen (1991) TCM construct.

\subsection{Self-management and Organization commitment}

Leadership is about influence and for leaders to positively influence their subordinates they must possess the necessary skills and abilities like self-management. Leaders who know and can regulate their emotions are more likely to react to a problem in a more controlled manner and may be more accommodative to different views of the subordinates. Understanding and regulation of one's emotions as well as understanding other's emotions are factors that 
DOI: 10.14807/ijmp.v11i4.1031

affect interpersonal relations which means that leaders with the skill of self-management may influence the OC of employees (SALAMI, 2008).

This is because a leader who has the skill of self-management is able to manage stress and remain calm in case of a conflict which may in turn create a good working environment in an organization. This is supported by Salami (2008) findings that understanding and regulating of one's emotions as well as understanding other's emotions are factors that affect intrapersonal well-being and interpersonal relations which influence workers' attitudes to their colleagues, bosses, jobs and the organization.

\section{METHODOLOGY}

\subsection{Research Design}

This study employed a survey research design in order to investigate the influence of principals' self-management on the organizational commitment of teachers as moderated by teachers' self-efficacy.

\subsection{Study population and Sample}

The population for this study was all the 560 principals and all teachers in secondary schools in Nairobi, Machakos, Kajiado, and Kiambu Counties. The research sample size for this study consisted of 120 principals and 480 teachers. Simple random sampling was used to select the principals and teachers from each school. Stratified sampling was used to group the principals into male and female so as to have a representative of each gender and to select the number of principals in the selected four counties. Kothari (2004) notes that stratified sampling technique is applied in case the population from which a sample is to be drawn does not constitute a homogeneous group.

\subsection{Data Collection Method}

Data collection method for this study was by the use of questionnaire.

Self-management Questionnaire: Principals’ self-management was assessed using the Emotional Competency Inventory (ECI) v.2 which is a multi-rater assessment that combines self, subordinate, peer, and supervisor rating on the EI competencies (GOLEMAN, et. al., 2002). This study combined the principals and teachers to rate principals' self-management because research indicates that self-reports are subject to bias, especially in organizational contexts where people might be motivated to fake good (ROSETE \& CIARROCHI, 2005). 
DOI: 10.14807/ijmp.v11i4.1031

Eight items were composed from the four competencies of self-Management that is emotional self-control, transparency, adaptability, achievement orientation.

Teachers’ Self-efficacy Questionnaire: Teacher Sense of Efficacy Scale (TSES)) which consists of 12 items was used to measure teachers' self-efficacy. Tschannen-Moran; Woolfolk; Hoy (2001) posits that this measure is of reasonable length and useful for exploring the construct of teacher efficacy. The TSES measure three dimensions of efficacy for instructional strategies, student engagement, and classroom (student) management.

Organizational Commitment Questionnaire: The Meyer; Allen; Smith, (1993) TCM Employee Commitment Survey designed to measure the three dimensions of organizational commitment (AC, CC and NC) was used to measure teachers' OC. To avoid confusion the term organization was replaced by school and in some instance with the term job.

\subsection{Analysis and Presentation}

This study employed independent samples t-test, descriptive statistics, correlation analysis and multiple regression method to analyze data. Independent samples $t$-test was used to compare means of the two groups (male and female (BANDA, 2018). Descriptive statistics was analyzed in form of means, frequencies, percentages, and standard deviation. This study used Pearson' correlation analysis to determine the relationship between principals' selfmanagement, teachers' self-efficacy and OC. Multiple regression was used to determine how the principals' self-management (independent variable) correlated significantly with on teachers' OC (dependent variable).

The model for this study was:
a) $Y=\beta_{0}+\beta_{x} X+\varepsilon$
b) $Y=\beta_{0}+\beta_{X} X+\beta_{z} Z+\varepsilon$
c) $\quad Y=\beta_{0}+\beta_{x} X+\beta_{z} Z+\beta_{x Z} X Z+\varepsilon$

\section{RESULTS OF THE STUDY}

\subsection{Profile of the participants}

Data was collected from a total of 102 secondary school principals and 408 teachers. The results of the study indicate that $52 \%$ of the teachers were female and $48 \%$ were male, $42.2 \%$ of the principals were female whereas $57.8 \%$ were male. The ages of the respondents ranged from 25 years to above 50 years where $47.1 \%$ of the principals and $12.5 \%$ of teachers 
INDEPENDENT JOURNAL OF MANAGEMENT \& PRODUCTION (IJM\&P)

http://www.ijmp.jor.br

v. 11, n. 4, July-August 2020

ISSN: 2236-269X

DOI: 10.14807/ijmp.v11i4.1031

were 50 and above years of age. Most of the respondents (55.9\% of the principals and $73.3 \%$ of teachers) were degree holders.

\subsection{Independent t-test for the relationship between gender and study variables}

An independent sample $t$-test was conducted to test whether there were differences between the gender and the study variables. The results in Table 1 revealed that there was no significant difference between self-efficacy of the female and that of male teachers. The results of teachers' self-efficacy and gender revealed that the mean difference is significant (mean difference $=0.08, \mathrm{t}=-2.622, \mathrm{df}=406, \mathrm{p}$-value $=0.009$ ). Female teachers have higher selfefficacy than the male. For OC, the mean difference is not significant (mean difference $=-0.06$, $\mathrm{t}=-1.613, \mathrm{df}=406$, $\mathrm{p}$-value $=0.107)$.

This is contrary to Turunen (2011) study on employment and OC among employees in Finland, Germany, Great Britain, Spain and Sweden that found that women displayed strong commitment than men in all the comparison countries. The mean difference for principals' selfmanagement as rated by teachers is not significant ((mean difference $=-0.02, \mathrm{t}=-0.515, \mathrm{df}=$ 406, $\mathrm{p}$-value $=0.607)$ as the female had a higher self-management index.

Table 1: Independent T-Test for the relationship between Gender and Study Variables

\begin{tabular}{llrrr}
\hline \multicolumn{5}{c}{ Group Statistics } \\
\hline \multirow{2}{*}{ Self-efficacy: Teacher } & Gender & $\mathrm{N}$ Mean & Std. Deviation & Std. Error Mean \\
& Male & 1962.9524 & .27308 & .01951 \\
& Female & 2123.0326 & .33855 & .02325 \\
Organizational Commitment & Male & 1962.8262 & .36511 & .02608 \\
of teacher & Female & 2122.8866 & .38899 & .02672 \\
Self-Management: T & Male & 1962.8622 & .38209 & .02729 \\
& Female & 2122.8833 & .43702 & .03001 \\
\hline
\end{tabular}

\section{Independent Samples Test}

\begin{tabular}{|c|c|c|c|c|c|c|c|c|c|}
\hline & & $\begin{array}{l}\text { Levene's Test } \\
\text { for Equality of } \\
\text { Variances }\end{array}$ & & & t-test & for Equality & of Means & & \\
\hline & & & \multirow[b]{2}{*}{$\mathrm{t}$} & \multirow[b]{2}{*}{$\mathrm{df}$} & \multirow{2}{*}{$\begin{array}{l}\text { Sig. (2- } \\
\text { tailed) }\end{array}$} & \multirow{2}{*}{$\begin{array}{c}\text { Mean } \\
\text { Difference }\end{array}$} & \multirow{2}{*}{$\begin{array}{l}\text { Std. Error } \\
\text { Difference }\end{array}$} & \multicolumn{2}{|c|}{$\begin{array}{l}\text { 95\% Confidence } \\
\text { Interval of the } \\
\text { Difference }\end{array}$} \\
\hline & & Sig. & & & & & & Lower & Upper \\
\hline \multirow[t]{2}{*}{$\begin{array}{l}\text { Self Efficacy: } \\
\text { Teacher }\end{array}$} & $\begin{array}{l}\text { Equal } \\
\text { variances } \\
\text { assumed }\end{array}$ & 3.140 .077 & 2.622 & 406 & .009 & -.08024 & .03060 & -.14041 & -.02008 \\
\hline & $\begin{array}{l}\text { Equal } \\
\text { variances } \\
\text { not assumed }\end{array}$ & & $2.644^{-3}$ & 88.777 & .009 & -.08024 & .03035 & -.13991 & -.02058 \\
\hline $\begin{array}{l}\text { Organizational } \\
\text { Commitment of } \\
\text { teacher }\end{array}$ & $\begin{array}{l}\text { Equal } \\
\text { variances } \\
\text { assumed }\end{array}$ & .308 .579 & $1.613^{-}$ & 406 & .107 & -.06038 & .03743 & -.13395 & .01320 \\
\hline
\end{tabular}


INDEPENDENT JOURNAL OF MANAGEMENT \& PRODUCTION (IJM\&P)

http://www.ijmp.jor.br

v. 11, n. 4, July-August 2020

ISSN: 2236-269X

DOI: 10.14807/ijmp.v11i4.1031

\begin{tabular}{|c|c|c|c|c|c|c|c|c|c|}
\hline & $\begin{array}{l}\text { Equal } \\
\text { variances } \\
\text { not assumed }\end{array}$ & & 1.617 & .905 & .107 & -.06038 & .03733 & -.13377 & .01302 \\
\hline \multirow[t]{2}{*}{$\begin{array}{l}\text { Self Management: } \\
\text { Teacher }\end{array}$} & $\begin{array}{l}\text { Equal } \\
\text { variances } \\
\text { assumed }\end{array}$ & 1.242 .266 & -.515 & 406 & .607 & -.02101 & .04078 & -.10118 & .05916 \\
\hline & $\begin{array}{l}\text { Equal } \\
\text { variances } \\
\text { not assumed }\end{array}$ & & \multicolumn{2}{|c|}{$-.518404 .756$} & .605 & -.02101 & .04057 & -.10076 & .05874 \\
\hline
\end{tabular}

\subsection{Correlation Analysis of the study}

To establish whether there exists a relationship between the principals' selfmanagement and teachers' OC, Pearson Product-Moment Correlation Coefficient matrix was used. According to Obilor; Esezi; Amadi; Eric (2018), the larger the $p$-value, the stronger the relationship and a smaller $p$-value denotes more significant relationship. A correlation coefficient of -1 and +1 indicate perfect negative and perfect positive correlation respectively.

If Pearson's $r$ is zero it means there is absolutely no association or there is zero correlation between the variables. Table 2 shows that principals' self-management (X) had a moderate and positive correlation with teachers' OC ( $\mathrm{r}=0.343, p$-value $<0.001)$. This indicates that improved self-management among the principals will result in an increased teachers' OC of $34.3 \%$. The correlation between self-management and self-efficacy was moderate and positive (0.404).

Table 2: Correlation Matrix for the Study Variables

\begin{tabular}{|c|c|c|c|c|}
\hline & & $\mathbf{Y}$ & $\mathbf{X}$ & $* \mathbf{M}$ \\
\hline & & $\begin{array}{l}\text { Teachers } \\
\text { Commitment }\end{array}$ & Self-Management & Self-Efficacy: Teacher \\
\hline \multirow[t]{2}{*}{$\mathrm{Y}$} & \begin{tabular}{|l} 
Pearson \\
Correlation
\end{tabular} & 1 & & \\
\hline & Sig. (2-tailed) & & & \\
\hline & $\mathrm{N}$ & 408 & & \\
\hline \multirow[t]{3}{*}{ X } & $\begin{array}{l}\text { Pearson } \\
\text { Correlation }\end{array}$ & $.343^{* *}$ & 1 & \\
\hline & Sig. (2-tailed) & .000 & & \\
\hline & $\mathrm{N}$ & 408 & 408 & \\
\hline \multirow[t]{3}{*}{ M } & \begin{tabular}{|l} 
Pearson \\
Correlation
\end{tabular} & $.163^{* *}$ & $.404^{* *}$ & 1 \\
\hline & Sig. (2-tailed) & .001 & .000 & \\
\hline & $\mathrm{N}$ & 408 & 408 & 408 \\
\hline
\end{tabular}

Key: Y= Organizational Commitment; X=Self-Management; M=Self-Efficacy. 
DOI: 10.14807/ijmp.v11i4.1031

\subsection{Regression results for the relationship between principals' self-management and teachers' organizational commitment}

The study hypothesized that:

- $\mathbf{H}_{02}$ : There is no significant influence of principal's self-management on the organizational commitment of teachers.

To test the hypothesis, the model $Y=\beta_{0}+\beta X+\varepsilon$ was fitted. The regression model in Table 3 (a) reveal that the relationship between principals’ self-management (X) and teachers' OC $(Y)$ was significant $(F(1,406)=54.139$, p-value $<0.001)$. According to Table 3 on regression coefficient, the regression model between self-management and organizational commitment was given as:

$$
\mathrm{Y}=7.358+0.343 \mathrm{X}
$$

The standardized coefficient for self-management was significant $(\beta=0.343, t=7.358$, p-value<0.001) which implies that for one unit increase in principals' self-management, organizational commitment of teachers increases by 0.343 . Self- management explains $12 \%\left(r^{2}\right.$ $=0.118$ ) of the variation of organizational commitment which implies that other factors outside self-management explain $88 \%$ of variation in organization commitment. Since $\beta$ is significantly different from zero $(t=7.358$, $p$-value $<0.001)$, the null hypothesis is rejected $\left(\mathrm{H}_{0}: \beta=0\right)$ and the conclusion is that principals' self-management significantly influences teachers' organizational commitment. This means that higher principals' self-management increases teachers' commitment. The regression analysis results between principals' self-management and teachers OC are shown in Table 3

Table 3: Regression Results for the Relationship between Principals’ Self-Management and Teachers' Organizational Commitment

\section{Model Summary}

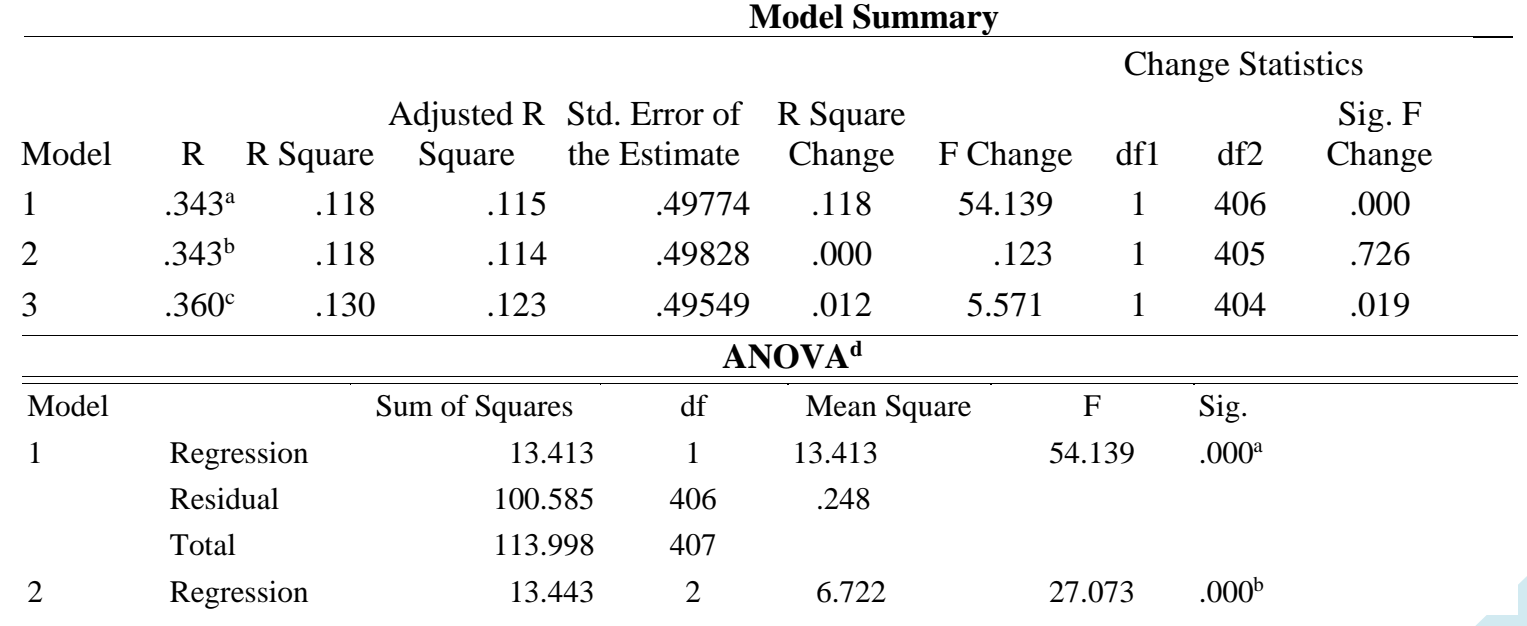


DOI: 10.14807/ijmp.v11i4.1031

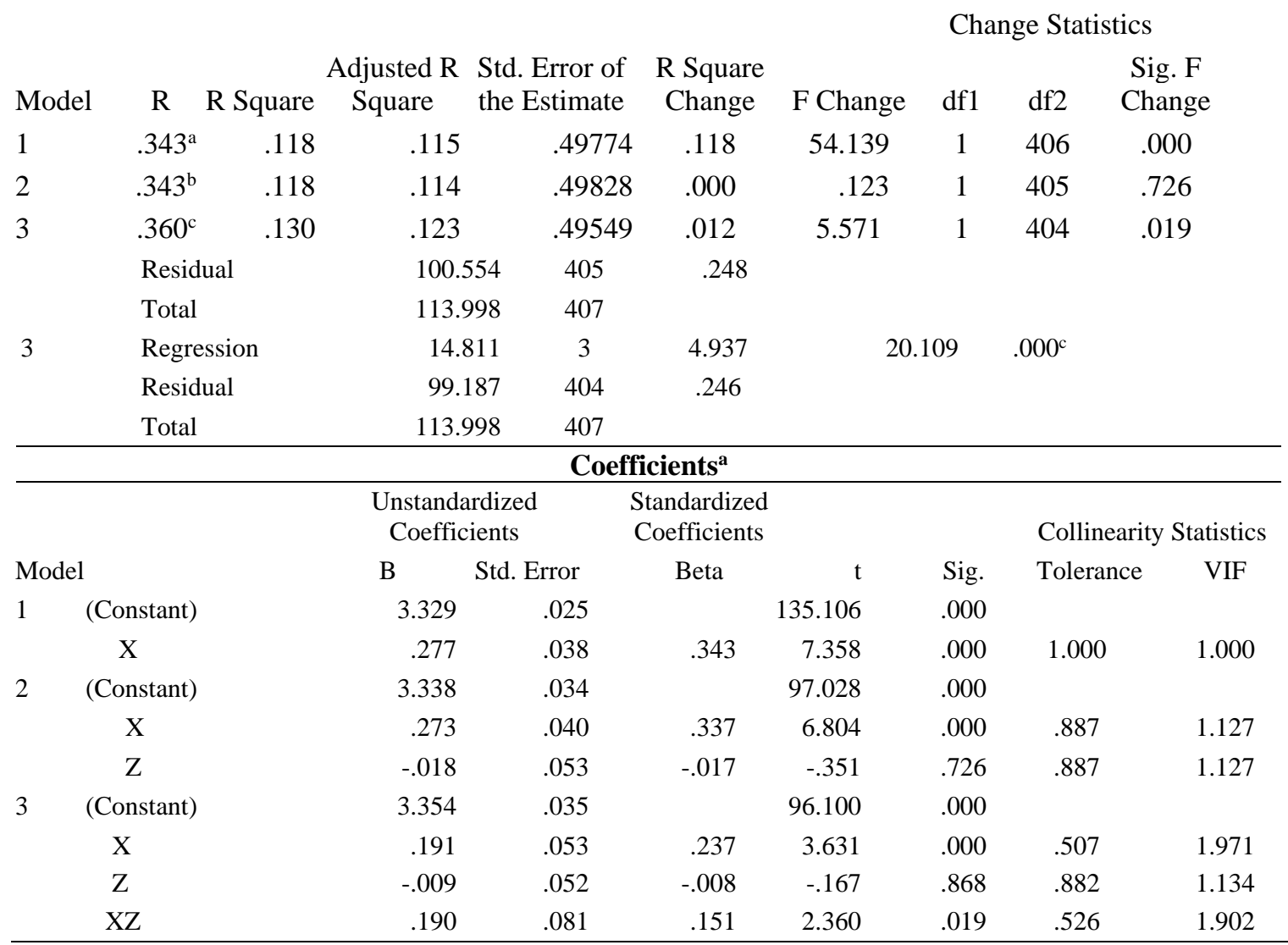

a. Predictors: (Constant), X; b. Predictors: (Constant), X, Z; c. Predictors: (Constant), X, Z, XZ; d. Dependent Variable: Teachers Commitment

\subsection{Moderating effect of self-efficacy on the relationship between principals' self- management and teachers' organizational commitment}

The hypothesis for this study was:

$\mathbf{H}_{\text {02: }}$ there was no significant moderating influence on the relationship between principals’ self-management and OC of teachers.

The result on the moderating effect of $\mathrm{Z}$ (self-efficacy) on the relationship between selfmanagement (X) and organizational commitment $(\mathrm{Y})$ indicate that all the three models were significant $(F(1,406)=54.139$, p-value $<0.001 ; \mathrm{F}(2,405)=27.073$, p-value $<0.001 ; \mathrm{F}(3,404)$ $=20.108$, $\mathrm{p}$-value $<0.001)$. From the model summary, the $\mathrm{F}$ change for $\mathrm{X}$ was significant implying that X significantly influences $\mathrm{Y}$. On adding the Z (self-efficacy) as a predictor to the model containing $\mathrm{X}$, the $\mathrm{F}$ change reduced drastically and was not significant (F2 Change $=0.123$, p-value $=0.726$ ).

With the introduction of the interaction term (XZ), the model improved substantially and was significant (F3 Change $=5.571$, $\mathrm{p}$-value $=0.019$ ). The implication of this was that some predictive value moderated between self-management and organizational commitment. 
DOI: 10.14807/ijmp.v11i4.1031

Therefore we reject the null hypothesis and conclude that self-efficacy is a significant moderator in the relationship between self-management and OC.

Self-efficacy moderation in the relationship between principals' self-management and teachers' OC is further implied by the intersecting lines in the scatter plot (Figure 1). The figure indicates that an increase in the principal's self-management index generally results in the increase in teachers' commitment. The rate of increase in OC is however higher for teachers with low self-efficacy than with those with high self-efficacy. The results of the scatter plot are shown in Figure 1.

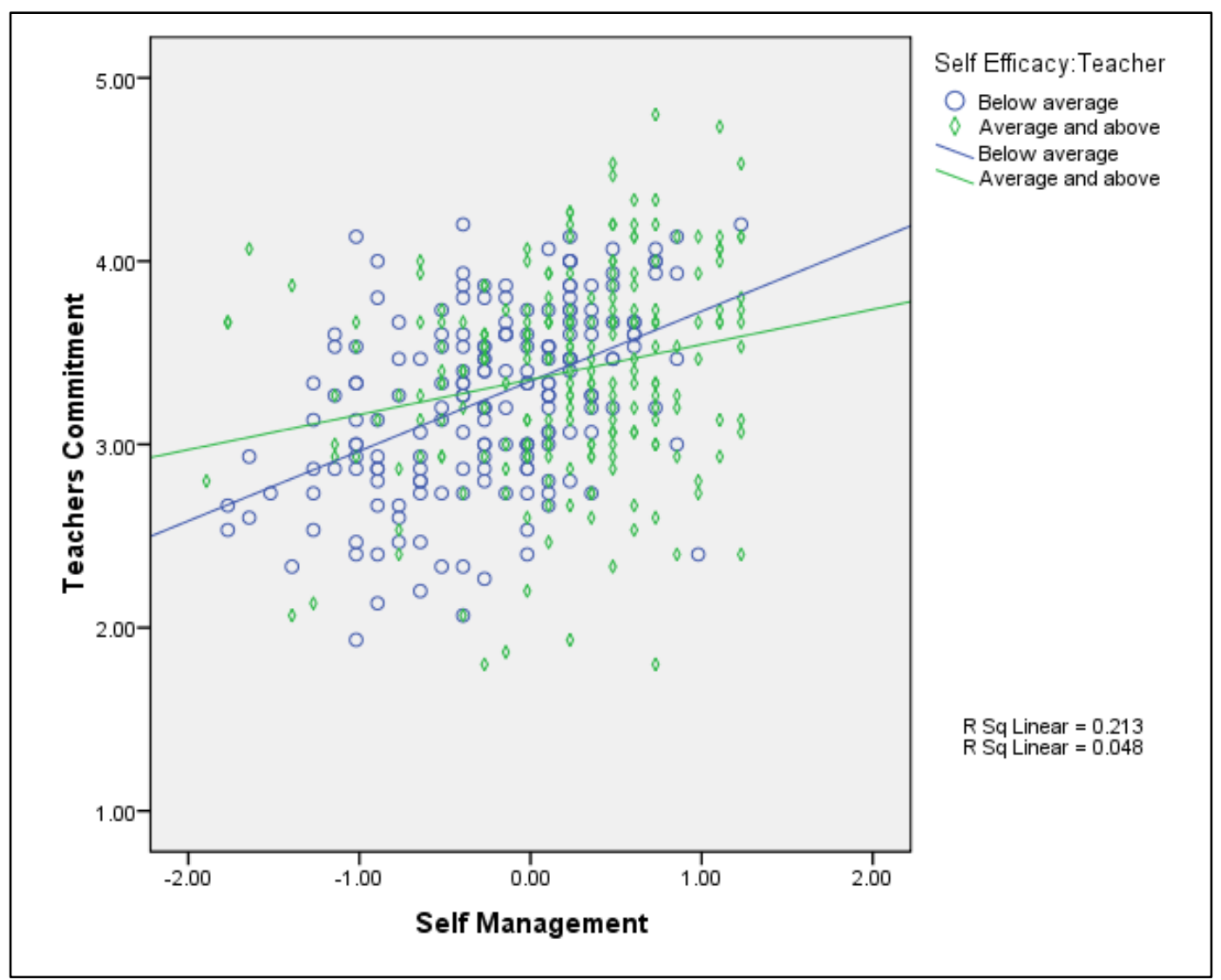

Figure 1: Scatter Plot on Moderating Effect of Self-efficacy on the Relationship between Principals’ Self-management and Teachers’ Organizational Commitment

\section{DISCUSSION AND CONCLUSION}

Previous studies indicate consistent significant correlation between the self-management and OC (QURESHI et al., 2015; VOLMER, 2012). We hypothesized that principals' selfmanagement has no signification relationship with teachers' OC. Regression results reveal that there is a significant relationship between principals' self-management and teachers OC $\left(\beta_{2}=\right.$ 0.343, $\mathrm{t}=7.358$, $\mathrm{p}$-value $\mathrm{p}$-value $<0.001$ ). 
INDEPENDENT JOURNAL OF MANAGEMENT \& PRODUCTION (IJM\&P)

http://www.ijmp.jor.br

v. 11, n. 4, July-August 2020

ISSN: $2236-269 X$

DOI: 10.14807/ijmp.v11i4.1031

The results indicated a positive correlation between self-management and organizational commitment. This implies that for one unit increase in principals' selfmanagement, teachers' OC increases by about 0.343. This is consistent with Newcombe; Ashkanasy (2002) findings that self-management is an important leadership skill that influences subordinates' positive work emotions and attitudes as it has ability to control disruptive or harmful emotions. The results of the findings indicated moderate agreement with all the items related to self-management. This study confirms that the ability to keep in check disruptive impulse and remain calm in times of crisis among the principals improves the commitment of teachers. Hence the null hypothesis was rejected.

The findings also corroborate with those of Qureshi, et al. (2015) that one of the selfmanagement competencies that is emotional self-control had a considerable impact on employees OC. Understanding and regulation of one's emotions as well as understanding other's emotions are factors that affect interpersonal relations which mean that selfmanagement of leaders may influence the OC of an employee (SALAMI, 2008). This is because a leader who is able to regulate their emotions can express excitement even when annoyed with the subordinates which in turn elevates the followers' emotional state. The regression results also indicate that self-efficacy is a significant moderator in the relationship between principals' self-management and teachers' OC.

\subsection{Practical Implication}

The results of our study have important implications for management practice. This article has found that principals’ self-management has significant influence on teacher' OC. Emotional intelligence training may be a powerful tool that organizations can employ to enhance OC of their employees. Little research has explored the moderating role of selfefficacy in the relationship between principals' self-management and teachers' OC; therefore it makes significant contribution to the advancement of knowledge in academic sector in Kenya. Given that most research on principals’ self-management and teachers' OC has been conducted outside Kenya (CARMELI, 2003; KHALILI, 2011; COETZEE, PAUW, 2013), findings from our study demonstrate that the effects of these two variables are not only limited to those other countries.

\subsection{Recommendations of the study}

This study suggests that development programmes for principals should include the study of self-management as part of education management training programmes in order to 
INDEPENDENT JOURNAL OF MANAGEMENT \& PRODUCTION (IJM\&P)

http://www.ijmp.jor.br

v. 11, n. 4, July-August 2020

ISSN: $2236-269 X$

DOI: 10.14807/ijmp.v11i4.1031

build and enhance their self-management. Better still this may be included in curriculum of institutions that train student teachers such as universities in order to enhance their EI. Teachers' Service Commission (teacher employer in Kenya) should include self-management as an important skill during recruitment of new principals or teachers.

The study also recommends that TSC should provide new teachers with guided mastery experiences and come up with ways of building their self-efficacy such as job enrichment. Job enrichment helps to provide immediate evaluation of their work hence making people work harder as they find their work more exciting. Similarly, school principals should be encouraged to give frequent verbal encouragement to the teachers which will help them overcome selfdoubt and improve their self-efficacy.

The study confined itself to Nairobi, Machakos, Kajiado, and Kiambu counties; hence more research could be carried out in other counties in Kenya to verify these findings. Since principals' self-management significantly influences teachers' OC, this study recommends that more research could be carried out in other sectors on the effects of leaders' self-management on employees' OC. To fully understand principals OC, further research needs to be carried out on perceived organizational commitment of principals by teachers. This study mainly examined the effects of principals' self-management on teachers OC; other emotional intelligence dimensions may be incorporated in future research to determine their effects.

\subsection{Drawbacks Factors and Limitations of the study}

Though the research used the teachers to rate principals' self-management for fear of biases, the results had no major differences between the principals' ratings and those by teachers. Secondly, the fact that the study was cross-sectional in nature rather than longitudinal it did not allow affirmative causal explanations.

The results of this study are drawn from data collected from education sector as such; generalization of the findings to other sectors might be limited. Finally the researcher had limited resources to collect data from the four counties in Kenya. This was resolved by requesting the assistance of some county directors who would issue questionnaires to sampled principals during meetings.

\section{REFERENCES}

ADEDOYIN, O. O. (2010) Factor-analytic study of teachers' perceptions on self-efficacy in Botswana junior secondary schools: implication for educational quality. European Journal of Educational Studies, v. 2, n. 2. 
DOI: 10.14807/ijmp.v11i4.1031

ALBDOUR, A.; ALTARAWNEH, I. (2014) Employee engagement and organizational commitment: evidence from Jordan. International Journal of Business, v. 19, n. 2, p. 10834346.

ALLEN, N. J.; MEYER, J. P. (1990) The measurement and antecedents of affective continuance, and normative commitment to the organization. Journal of Occupational Psychology, n. 63, p. 1-18.

ALLINDER, R. M. (1994) The relationship between efficacy and instructional practices of special education teachers and consultant. Teacher Education and Special Education, n. 17, p. 86-10.

BANDA, G. (2018) A brief review of independent, dependent and one sample t-test. International Journal of Applied Mathematics and Theoretical Physics, v. 4, n. 2, p. 50-5.

BANDURA, A. (1997) Self-efficacy: the exercise of control. In Tschannen-Moran, M. Gareis, C. R. (2007). Cultivating principals' sense of efficacy: support that matter. Journal of School Leadership, n. 7, p. 89-25.

BANDURA, A. (1986) Social foundations of thought and action: a social cognitive theory. In BANDURA, A. (2001) Social cognitive theory: an agentic perspective. Annual Review Psychology, n. 52, p. 1-26.

CARMELI, A. (2003) The relationship between emotional intelligence and work attitudes, behavior and outcomes: An examination among senior managers. Journal of Managerial Psychology, v. 18, n. 8, p. 788-25

CAPRARA, G. V.; BARBARANELLI, C.; STECA, P.; MALONE, P. S. (2006) Teachers' selfefficacy beliefs as determinants of job satisfaction and students' academic achievement: a study at the school level. Journal of School Psychology, n. 44, p. 473-17.

CHERNISS, C.; GOLEMAN, D. (2001) The Emotionally intelligent workplace: how to select for, measure, and improve emotional intelligence in individuals, groups, and organizations. San Francisco: Jossey-Bass.

COETZEE, W.; PAUW, D. (2013) Staff perception of leader emotional competency as a predictor of satisfaction with retention factors. Journal of Psychology in Africa, v. 23, n. 2, p. 177-9.

COHEN, A. (2006) The relationship between multiple commitment and organizational citizenship behavior in Arab and Jewish Culture. Journal of Vocational Behavior, n. 69, p. 105-13.

COHEN, A. (1999) Relationships among Five Forms of Commitment: An Empirical Assessment. Journal of Organizational Behavior, n. 20, p. 285-23.

COLADARCI, T. (1992) Teachers' sense of efficacy and commitment to teaching. Journal of Experimental Education, v. 60, n. 4, p. 323-14.

COLQUITT, J.; LEPINE, J.; WESSON, M. (2009) Organizational behavior: improving performance \& commitment in the workplace. New York: McGraw-Hill.

DAFT, R. (2008) The leadership experience, $4^{\text {th }}$ ed. London: South-Western.

GEORGE, J. M. (2000) Emotions and leadership: the role of emotional intelligence. Human Relations, n. 53, p. 1027-28.

GIST, M. E.; MITCHELL, T. R. (1992) Self-efficacy: a theoretical analysis of its determinants and malleability. Academy of Management Review, v. 17, n. 2, p. 183-18. 
DOI: 10.14807/ijmp.v11i4.1031

GOLEMAN, D.; BOYATZIS, R.; MCKEE, A. (2002) Primal leadership: realizing the power of emotional intelligence. Boston: Harvard Business School Press.

GOLEMAN, D. (2001) An EI-based theory of performance. In CHERNISS, C.; GOLEMAN, D. (Ed), The Emotionally Intelligent Workplace: How to Select for, Measure, and Improve Emotional Intelligence in Individuals, Groups, and Organizations. San Francisco: Jossey-Bass. P. 60-35.

GOLEMAN, D. (1998b) What makes a leader? Harvard Business Review, n. 76, p. 93-10.

GOLEMAN, D. (1995). Emotional intelligence. In Zeidner, M., Matthews, G. \& Roberts, R., D. (2004). Emotional Intelligence in the Workplace: A Critical Review. Applied Psychology: An International Review, v. 53, n. 3, p. 371-28.

GUSKEY, T. R.; PASSARO. P. D. (1994) Teacher efficacy: a study of construct dimensions. American Educational Research Journal, n. 31, p. 627-16.

KENYA NATIONAL UNION OF TEACHERS (2015) Report on Trends of the Needs of Teachers in Public Schools in Kenya.

KHALILI, A. (2011) Examining the relevance of emotional intelligence and organizational commitment among employees of small and medium enterprise in private sector. International Journal of Business and Management, v. 6, n. 12, ISSN 1833-3850, E-ISSN 1833-8119.

KHOSRAVI, B.; MANAFI, M.; HOJABRI, R.; AGHAPOUR, A.; GHESHMI, R. (2011) The relationship between emotional intelligence and effective delegation. International Journal of Business and Social Science, v. 2, n. 19, p. 223-13.

KOTHARI, C. R. (2004) Research methodology: Methods and techniques. $\left(2^{\text {nd }}\right.$ Revised ed.).New Delhi: New Age International (P) Publishers.

MATHIEU, J. E.; ZAJAC, D. M. (1990) A review and meta-analysis of antecedents, correlates and consequences of organizational commitment. Psychological Bulletin, n. 108, p. 171-23.

MEYER, J. P.; HERSCOVITCH, L. (2001) Commitment in the workplace: toward a general model. Human Resources Management Review, n. 11, p. 299-27.

MEYER, P. J.; ALLEN, J. N. (1997) Commitment in the workplace: theory, research, and application. In Cohen, A. (2006) The relationship between multiple commitment and organizational citizenship behavior in Arab and Jewish culture. Journal of Vocational Behavior, n. 69, p. 105-13.

MEYER, J. P.; ALLEN, N. J.; SMITH, C. A. (1993) Commitment to organizations and occupations: extension and test of a three-component conceptualization. Journal of Applied Psychology, v. 78, n. 4, p. 538-55.

MEYER, J. P.; ALLEN, N. J. (1991) A three-component conceptualization of organizational commitment. Human Resource Management Review, v. 1, n. 1, p. 61-28.

MILNER, H. R.; WOOLFOLK HOY, A. (2003) A case study of an African American teacher's self-efficacy, stereotype threat, and persistence. Teaching and Teacher Education, n. 19, p. 263-13.

MOWDAY, R. T. (1998). Reflections on the study and relevance of organizational commitment. Human Resource Management Review, v. 8, n. 4, p. 387-14. 
DOI: 10.14807/ijmp.v11i4.1031

MURPHY, D. P. (2013) An examination into the relationship between teacher efficacy and organizational commitment of special education teachers. Thesis (PhD in Education Leadership). Massachusetts.

NEWCOMBE, M. J.; ASHKANASY, N. M. (2002) The role of affect and affective congruence in perceptions of leaders: An experimental study. Leadership Quarterly, n. 13, p. 601-14.

NEWSTROM, J. W.; DAVIS, K. (1997) Organizational behavior: human behavior at work. New York: McGraw Hill.

OBILOR, E.; AMADI, E. (2018) Test for significance of Pearson’s Correlation Coefficient. International Journal of Innovative Mathematics, Statistics \& Energy Policies v. 6, n. 1, p.11-12.

QURESHI, I. A.; ALI, R.; RAZA, H.; WHITTY, M. (2015) The impact of leader's emotional intelligence on employee commitment: an empirical study in the sports industry of Sialkot, Pakistan. Journal of Business and Management, v. 17 n. 1, p. 125-9.

ROSETE, D.; CIARROCHI, J. (2005) Emotional intelligence and its relationship to workplace performance outcomes of leadership effectiveness. Leadership and Organization Development Journal, v. 26, n. 5, pp. 388-11.

SALAMI, S. (2008) Demographic and psychological factors predicting organizational commitment among industrial workers. Anthropologist, v. 10, n. 1, p. 31-38.

SOLINGER, O. N.; VAN OLFFEN, W.; ROE, R. A. (2008) Beyond the three-component model of organizational commitment. Journal of Applied Psychology, v. 93, n. 1, p. 70-13.

TSCHANNEN-MORAN, M.; WOOLFOLK HOY, A. (2001) Teacher efficacy: capturing an elusive construct. Teacher and Teacher Education, n. 17, p. 783-22.

TURUNEN, T. (2011) Commitment to employment and organization: Finland in a European comparison. Research on Finnish Society, n. 4, p.55-11.

VOLMER, J. (2012) Catching leaders' mood: contagion effects in teams. Administrative Sciences, n. 2, p. 203-23.

ZEIDNER, M.; ROBERTS, R.; MATTHEWS, G. M. (2002) Can emotional intelligence be schooled? A critical review. In ZEIDNER, M.; MATTHEWS, G.; ROBERTS, R. D. (2004) Emotional intelligence in the workplace: a critical review. Applied Psychology: An International Review, v. 53, n. 3, p. 371-28. 